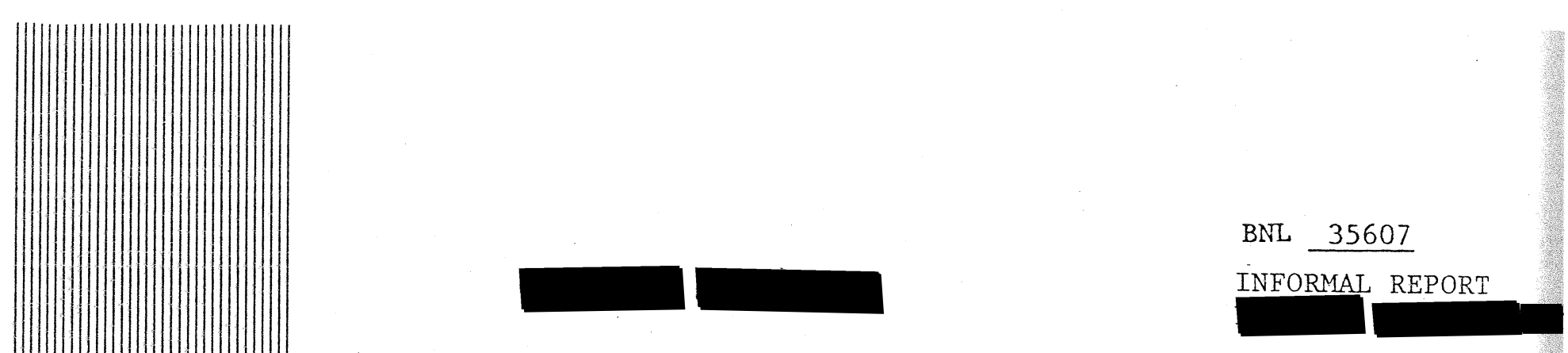

FLASH PYROLYSIS OF BIOMASS WITH REACTIVE AND NON-REACTIVE GASES

Summary Report for Period July 1983 - September 1984

M. Steinberg, P. T. Fallon, and M. S. Sundaram

October 1984

Prepared for

THERMOCHEMICAL CONVERSION DIVISION

BATTELLE PACIFIC NORTHWEST LABORATORY

RICHLAND, WASHINGTON

DEPARTMENT OF APPLIED SCIENCE

BROOKHAVEN NATIONAL LABORATORY UPTON, LONG ISLAND, NEW YORK 11973

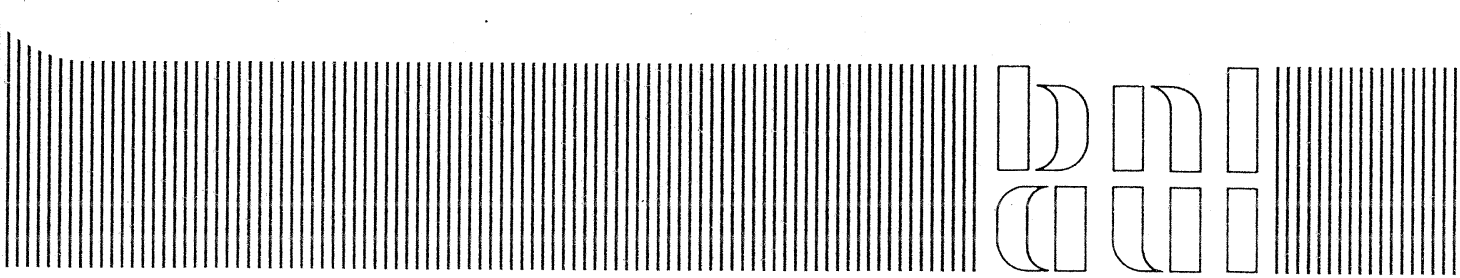


BNL 35607

INFORMAL REPORT

LIMITED DISTRIBUTION

\section{FLASH PYROLYSIS OF BIOMASS WITH REACTIVE AND NON-REACTIVE GASES \\ Summary Report for Period July 1983 - September 1984}

M. Steinberg, P. T. Fallon, and M. S. Sundaram

October 1984

Prepared for the

THERMOCHEMICAL CONVERSION DIVISION

BATTELLE PACIFIC NORTHWEST LABORATORY

RICHLAND, WASHINGTON

M. STEINBERG, Division Head

Process Sciences Division

Department of Applied Science

Brookhaven National Laboratory ASSOCIATED UNIVERSITIES, INC.

Under Contract No. DE-AC02-76CH00016 with the U.S. Department of Energy 
DISCLAIMER

This report was prepared as an account of work sponsored by an agency of the United States Government. Neither the United States Government nor any agency thereof, nor any of their employees, nor any of their contractors, subcontractors, or their employees makes any warranty, express or implied, or assumes any legal liability or responsibility for the accuracy, completeness, or usefulness of any information, apparatus, product or process disclosed, or represents that its use would not infringe privately owned rights. Reference herein to any specific commercial product, process, or service by trade name, trademark, manufacturer, or otherwise, does not necessarily constitute or imply its endorsement, recommendation, or favoring by the United States Government or any agency thereof. The views and opinions of authors expressed herein do not necessarily state or reflect those of the United States Government or any agency, contractor, or subcontractor thereof. 
Flash Pyrolysis of Biomass with Reactive and Non Reactive Gases (Report Period - July 1983-September 1984)

\section{SUMMARY}

The purpose of this program is to study the conversion of biomass to liquid and gaseous hydrocarbon fuels and chemical feedstocks by a flash or rapid pyrolysis technique. During this period of study pine wood was flash pyrolyzed in atmospheres of methane and helium at a pressure of 50 psi and at temperatures up to $1050^{\circ} \mathrm{C}$. The $1^{\prime \prime}$ I.D. entrained downflow tubular reactor was used in these experiments. Product yields of methane, ethane, ethylene, BTX, carbon monoxide and carbone dioxide were determined as a function of temperature and gas to wood ratio. Of particular interest were the ethylene and BTX yields. These represented as much as $29.6 \%$ and $24.6 \%$ of the carbon contained in the feed wood respectively when flash pyrolyzing in methane (flash methanolysis) and $14.7 \%$ and $9.7 \%$ when pyrolyzing in helium. In the case of flash methanolysis of wood the yields of ethylene and benzene increased with increasing methane to wood feed ratios. In the case of flash pyrolysis in helium the yields of ethylene and BTX decreased with increasing helium gas to wood feed ratios. These results indicate a mechanism by which a free radical reactive species originating from the wood interacts with the methane pyrolyzing gas to produce an enhanced yield of ethylene and benzene. The flash methanolysis of lignin extract from wood produced lower yields of ethylene, indicating the yields mainly originate from the cellulosic fractions of the wood. Some work was also performed on substituting wood ash for silica flour ( $\mathrm{Cab}-\mathrm{O}-\mathrm{Sil}$ ) to allow free flow of wood particles through the entrained flow reactor. Preliminary process design and analysis indicates an economically competitive process for the flash methanolysis of wood for the production of methanol, benzene and ethylene. Future plans include completing the studies on obtaining the process chemistry of the flash methanolysis of woods, to obtain a better understanding of the enhanced ethylene and benzene yield and to investigate other biomass forms. 

Pine wood was rapidly pyrolyzed in an atmosphere of methane (flash methanolysis) at $50 \mathrm{psi}$ methane pressure and at reactor temperatures of $900^{\circ} \mathrm{C}$ to $1050^{\circ} \mathrm{C}$. The experiments were conducted in the BNL downflow entrained tubular reactor having dimensions of 1 " I.D. by $8 \mathrm{ft}$. long. A methane pressure of 50 psi was chosen from experience with other materials including fir wood which showed hydrocarbon yields to be a maximum at this methane pressure. The results are given in Table 1 . In the first 5 experiments reported, the ratio of methane to wood was greater than 6 , indicating a dilute wood phase in the reactor. These results are plotted in Figure 1. The ethylene and BTX yields both increase with increase temperature reaching a maximum of $28 \%$ and $24 \%$ respectively at $1000^{\circ} \mathrm{C}$ after which both yields are seen to decline as the reactor temperature is further increased to $1050^{\circ} \mathrm{C}$. In Figure 2, the ethylene and BTX yields for methane to wood ratios down to 1.32 (increasing the density of the wood phase in the reactor) and at a reactor temperature of $1000^{\circ} \mathrm{C}$ are plotted as a function of these ratios. The yields of both products show a strong dependency upon this ratio, the BTX to a lesser degree than the ethylene. While the ethylene decreased from $29.6 \%$ at a ratio of 9.36 down to $7.5 \%$ at a ratio of 1.32 , the BTX decreased from $23.7 \%$ down to $13.8 \%$ at the same ratios. The ethylene yields for these same experiments were then plotted along with the ethylene concentration in the process stream for these experiments, Figure 3. Although the data is scattered, it does show the trade-off between obtaining high ethylene concentrations versus high yields. For example, al though concentrations of ethylene as great as $2.35 \%$ by volume were achieved, the yields were only $7.5 \%$ to $14.7 \%$ while at the higher yield of $27.4 \%$, the concentration was only $1.31 \%$. Examining the data further, it is noted that although experiments 777 and 792 were both run at a methane to wood ratio of approximately 4 , the results differ by approximately $30 \%$ which seems greater than would be expected as a result of random error. This could be attributed to the large differences of approximately $40 \%$ in the absolute methane and wood feed rates even though the ratios were the same. Further experiments of this type appear to be in order. 
Some difficulty was experienced in measuring the carbon monoxide yields due to the closeness of the retention times of this and the methane on the G.C. column being used. Generally, the Co yields were in the order of $35 \%$ to $40 \%$ with most results closer to $40 \%$. The carbon dioxide yields were generally $3 \%$ or slightly less and some small quantities of ethane $(\leq 2.1 \%)$ were produced at methane to wood ratios of less than 4. The overall results of these experiments would indicate that approximately $28 \%$ ethylene, $24 \%$ BTX and $40 \%$ carbon monoxide can be produced from the flash methanolysis of pine for an overall yield of over $90 \%$ useful products.

During these flash methanolysis experiments, considerable attention was given to determining whether or not hydrocarbon product yields reported were a result of reactions leading to a large consumption of methane. For this purpose, a mass flowmeter was placed in the feed line and the effluent methane was monitored via a positive displacement meter and G.C. measurements of the methane concentration in this gas. The results were slightly scattered but indicated negligible consumption of methane if any and possibly even some production. Experiments were also conducted adding $6 \%$ helium to the methane with the purpose of measuring the helium to methane ratios in both the feed and the effluent. If this ratio increased, it would indicate a net consumption and a decrease would indicate a net production of methane. Although problems with retention of helium on the G.C. column used made these experiments inconclusive the information gathered would tend to show negligible consumption of methane.

Before each experiment involving flash methanolysis, gas samples or blanks are taken to measure any possible hydrocarbon products that may be present in the feed gas. In most cases, particularly when using high grade methane $(+99 \%)$ the gaseous hydrocarbon contaminants seldom exceed $0.15 \%$ of which approximately half or $0.075 \%$ is ethylene and half ethane. Considering the ethane concentrations in the process stream for most experiments is about $1 \%$ or greater, this does not represent a significant fraction of the product and in any case this background value is deducted from the measured value in calculating yields. When less pure methane is used, the ethylene in the feed gas at reactor conditions may be as great as $0.2 \%$. Again when calculating yields, this is taken into consideration and little difference 
is seen in the overall results. Only the higher purity methane is now used in flash methanolysis experiments.

The methane to wood ratio experiments shown in Figure 3 indicate a non-Iinear increase in ethylene yield (based on the wood carbon) as a function of the methane to wood ratio. This would indicate that the ethylene yield depends on a species formed from the pyrolysis of wood reacting with the methane. If there were an, independent additive yield of ethylene from wood and from methane, the total yield should be linear with respect to the methane to wood ratio. From a carbon mass balance, the partial additive conversion to ethylene is expressed as follows.

$$
\mathrm{C}_{\mathrm{C}_{2} \mathrm{H}_{4}}=\times \mathrm{C}_{\mathrm{CH}_{4}}+\mathrm{yC}_{\mathrm{w}}
$$

where

$$
\begin{aligned}
\mathrm{C}_{\mathrm{C}_{2} \mathrm{H}_{4}} & =\text { carbon converted to ethylene, wt or atom } \% \\
\mathrm{C}_{\mathrm{CH}_{4}} & =\text { carbon in methane, wt or a tom } \% \\
\mathrm{C}_{\mathrm{w}} & =\text { carbon in wood, wt or atom } \% \\
\mathrm{y} & =\text { yield, fraction of carbon in wood converted to } \mathrm{C}_{2} \mathrm{H}_{4}, \% \\
\mathrm{x} & =\text { yield, fraction of carbon in methane converted to } \mathrm{C}_{2} \mathrm{H}_{4}, \%
\end{aligned}
$$

Dividing by $\mathrm{C}_{\mathrm{w}}$, the following linear equation is obtained where the ratio $\mathrm{C}_{\mathrm{C}_{2} \mathrm{H}_{4}} / \mathrm{C}_{\mathrm{W}}$ is the ethylene yield based on wood carbon and $\mathrm{C}_{\mathrm{CH}_{4}} / \mathrm{C}_{\mathrm{W}}$ is the methane to wood ratio

$$
\frac{\mathrm{C}_{\mathrm{C}_{2} \mathrm{H}_{4}}}{\mathrm{C}_{\mathrm{w}}}=\mathrm{x} \frac{\mathrm{C}_{\mathrm{CH}_{4}}}{\mathrm{C}_{\mathrm{w}}}+\mathrm{y}
$$

The fact that the ethylene yield is non-linear with respect to the methane to wood ratio shows that the yield is non-independent with respect to methane and wood and that a species from the wood interacts with the methane. One possible mechanism is the formation of a free radical from the wood formed by pyrolysis reacting with methane forming methyl radicals which then combine to form ethane and the ethane cracking to ethylene. This mechanism can be expressed by the following reaction. 


$$
\begin{aligned}
& \text { wood } \underset{\Delta}{\longrightarrow} \text { free radicals }\left(\mathrm{CH} \cdot \mathrm{CH}_{2} \cdot, \mathrm{CH}_{3} \cdot \text {, etc. }\right)+\mathrm{H}_{2} \mathrm{O}+\mathrm{CO} \\
& \text { wood free radicals plus methane reaction. } \\
& \mathrm{CH}_{2} \cdot+\mathrm{CH}_{4}=\mathrm{CH}_{3} \cdot+\mathrm{CH}_{3} \cdot \\
& \mathrm{CH}_{3} \cdot+\mathrm{CH}_{3} \cdot=\mathrm{C}_{2} \mathrm{H}_{6} \\
& \mathrm{C}_{2} \mathrm{H}_{6}=\mathrm{C}_{2} \mathrm{H}_{4}+\mathrm{H}_{2}
\end{aligned}
$$

To resolve this mechanism issue, consideration is being given to an istotopic tracer experiment based on the natural $\mathrm{C}^{13}$ content of methane and wood and the $\mathrm{C}^{13}$ centers in the ethylene to determine how much carbon from the methane and carbon from the wood ends in forming the ethylene.

In another experiment, a small amount of ethylene ( $1.35 \%$ by volume) was added to the methane feed to determine whether any reactions take place between methane and ethylene in the reactor in the absence of wood. In running the $1.35 \%$ ethylene in methane mixture through the reactor in the absence of wood, the ethylene appeared to degrade with both time and temperature as given in Table 2. At $900^{\circ} \mathrm{C}$ the ethylene degrades from an initial concentration of $1.35 \%$ to $1.25 \%$ at a gas residence time of 0.5 seconds and to $1.1 \%$ at a residence time of 2 seconds. At a constant residence time of 0.5 seconds, the ethylene is reduced to $1.25 \%$ at $900^{\circ} \mathrm{C}, 1.15 \%$ at $1000^{\circ} \mathrm{C}$ and $0.9 \%$ at $1050^{\circ} \mathrm{C}$.

These results indicate that the ethylene yields produced from the interaction of methane with the wood (methanolysis) may originally be higher than measured because of secondary ethylene degradation reactions as concentrations exceed $1.35 \%$ at $1000^{\circ} \mathrm{C}$. We have measured concentrations as high as $2.35 \%$ in our methanolysis experiments under the same conditions with wood feed. This would indicate that shorter gas residence times might result in increased net ethylene yields. A mechanism for formation of ethylene by reaction of methylene free radicals with methane should have resulted in an increase in ethylene concentration according to the following reactions. Thus, for every mole of ethylene added, two noles of ethylene should be formed, according to the following mechanism.

$$
\begin{aligned}
& \mathrm{C}_{2} \mathrm{H}_{4}=\mathrm{CH}_{2}=+\mathrm{CH}_{2} \cdot \\
& 2 \mathrm{CH}_{2}=+2 \mathrm{CH}_{4}=2 \mathrm{C}_{2} \mathrm{H}_{4}+2 \mathrm{H}_{2}
\end{aligned}
$$


The fact that no additional ethylene was formed in this experiment, in which ethylene was added to the methane feed gas, indicates that this mechanism does not appear to be operative. Flash Pyrolysis of Pine in Helium

Pine wood was flash pyrolyzed in an atmosphere of helium at 50 psi in the same manner as the previously reported experiments using methane. The reactor temperature was varied from $800^{\circ} \mathrm{C}$ to $1050^{\circ} \mathrm{C}$ and the results are given in Table 3. In Figure 4 the results from experiments conducted at a helium to wood ratio of greater than 1 are plotted as a function of reactor temperature. As opposed to the methanolysis experiments where the maximum product yields were produced at $1000^{\circ} \mathrm{C}$, in the case of pyrolysis experiments in helium the maximum yields occurred at $900^{\circ} \mathrm{C}$. The gaseous hydrocarbons, methane, ethane and ethylene were the major hydrocarbon products, amounting to $27 \%$ of the carbon in the pine being converted to product. The only other hydrocarbon product of significance was the BTX which yielded approximately $8 \%$ at $900^{\circ} \mathrm{C}$ and increased slightly to $9 \%$ at $950^{\circ} \mathrm{C}$ and above. The carbon monoxide yields were generally in the order of $40 \%$ to $45 \%$ tending more toward the latter, again with some difficulty in the absolute measurement due to problems with the G.C. This gives a total of $80 \%$ useful products from the flash pyrolysis of pine.

In the next series of experiments, the helium to wood ratio was varied in order to determine the effect of increased product concentration, particularly the ethylene, on product yields. The results are plotted in Figure 5 and shows the BTX yield at $1000^{\circ} \mathrm{C}$ to be rather insensitive to the ratio, varying slightly between $8 \%$ and $9 \%$. The gaseous hydrocarbon yields decreased from approximately $27 \%$ as the helium wood ratio increased. This is directly opposite to what was previously seen when pyrolyzing in methane. In other words, the denser wood phase produced both higher yields and higher product concentrations. Most of this increase was due to an increase in ethylene as shown in Figure 6. The ethylene yield appears to reach a maximum of $11 \%$ even as the concentration is increased above $1 \%$ by decreasing the helium to wood ratio. Higher density wood phases and lower temperatures should be investigated to determine the ethylene concentration limits. Also the higher ethylene yields at higher densities of wood appears to support 
the mechanism of free radicals from the wood reacting with each other to form ethylene when no methane is present. When methane is present these radicals can react with methane which leads to an increase in ethylene yield especially in a more dilute phase with wood. The free radicals from the wood are efficiently used is methane to produce more than double the ethylene yield.

Flash Pyrolysis and Flash Methanalysis of Pine Using Wood Ash

In an effort to substitute the use of Cab-O-Sil (fine silica flour) as an additive for proper feeding of the wood in the flash pyrolysis experiments, ash from oak wood was substituted for the Cab-O-Sil in two experiments. Before using the ash, it was first fired in air at $1000^{\circ} \mathrm{C}$ for approximately 3 hours to remove all carbonaceous material and then sieved through a 147 micron screen to insure the use of only the smaller particles. In these two experiments, methane and pine wood were used at 50 psi and $1000^{\circ} \mathrm{C}$. The results plus those from similar experiments at the same conditions using Cab-0-Sil are given in Table 4. In the first experiment, Run No. $768,50 \%$ ash was added to the wood. However, some intermittent plugging of the reactor was still observed. In the next experiment, the ash was increased to $60 \%$, but the reactor again plugged; this time completely, approximately 25 minutes into the experiment. Sample of ash were fired at temperatures of $800^{\circ} \mathrm{C}, 850^{\circ} \mathrm{C}, 900^{\circ} \mathrm{C}$ and $1000^{\circ} \mathrm{C}$. At $900^{\circ}$ some fusing of the ash was noted and at $950^{\circ} \mathrm{C}$ the ash was fused completely. Evidently oak ash has some limitations in preventing agglomeration of wood particles. Other types of ash and sand should be tried to aid in the free flow of wood particles through the reactor. The results revealed good agreement with past results for the ethylene yields but an approximately $25 \%$ lower result was obtained for the BTX yields. Also, the experiments using ash produced more co than did those using Cab-O-Sil. The total carbon conversion balance for the two new experiments $(112.6 \%$ and $109.3 \%$ ) are obviously too high. The weight loss measurements are probably closer to the true total conversion for these experiments. When using Cab-O-Sil, some portion of the char escapes due to the very light nature of the char produced, resulting in high weight loss measurenents. Also, the retention time of the carbon monoxide and that of the methane are so close to one another in the on-line gas chromatograph, that some error in the measurement of the carbon monoxide yield is 
suspected. The analysis of the other products, ethylene, benzene and toluene, do not have this problem. The Co measurement problem only exists due to the large concentrations of methane ( $85 \%)$ and carbon monoxide ( $10 \%)$ in the product stream. By comparison, the ethylene concentration for these two experiments was approximately $2 \%$.

Flash Methanolysis of Lignin

For the purpose of attempting to separate the effect of the function of different parts of wood in determining yields, a flash methanolysis experiment was performed using lignin. Kraft pine lignin was used and was first tried without a flow enhancing additive, such as Cab-0-Sil, but the reactor plugged. Only after $20 \% \mathrm{Cab}-0-\mathrm{Sil}$ was added to the lignin would it flow properly, however some agglomeration of the char was noted after the completion of the experiment. In Table 5, the results are compared to results of a similar run obtained using fir wood under similar conditions. Table 5 shows that the lignin produces much lower yields of gaseous hydrocarbons and carbon monoxide compared to the whole wood. However, the BTX yield was higher for the lignin than for the wood, by a small margin ( $7.3 \%$ vs $5.8 \%$ ).

The lignin has a stoichiometric formula of $\mathrm{CHO}_{0.36}$ while the wood has a formula of $\mathrm{CH}_{1.440^{0}} .66$. Although the lignin contains approximately $50 \%$ as much oxygen as the wood, it only produces approximately $20 \%$ as much carbon monoxide based on carbon content. Assuming the lignin from fir wood to behave similar to that from pine, it would appear the major source of ethylene and carbon monoxide when pyrolyzing in a methane atmosphere is the cellulose from the wood and not the lignin. The larger BTX yield may be due to the higher aromatic structure of the lignin compound to the wood cellulose. Cellulose will be used in the near future for a further comparison. It should also be noted that the Kraft process for obtaining lignin could alter the structure of the lignin so that the results are not completely definitive. However, these results give an indication of the possible mechanism of the yields obtained. 
Process Design and Analysis

A preliminary process design and economic analysis for the flash methanolysis of wood was prepared by $E$. Wan Scientific Applications, Inc., and presented at the 16 th Biomass Contractors Meeting (May 1984). The process was based on the production of ethylene and benzene and the conversion of the co to methanol. The results indicated an economically competitive process in comparison with the production of methanol by wood gasification and catalytic conversion of the synthesis gas.

Future Plans

It is planned to complete the studies on the process chemistry of the flash methanolysis of wood and to obtain a further insight into the mechanism of the enhanced formation of ethylene and benzene. It is also planned to study the flash methanolysis of other biomass forms including hardwoods, cellulose, peanut shells and other agricultural residues. 


\section{List of Publications}

1. Steinberg, M. "Flash Pyrolysis of Biomass with Reactive and NonReactive Gases." Paper presented at the 15th Biomass Thermochemical Conversion Contractors' Meeting, BNL 32746, Atlanta, Georgia, 16-17 March 1983.

2. Sundaram, M.S., Steinberg, M., and Fallon, P.T. "Characterization of the Products and Comparison of the Product Yields from the Flash Pyrolysis of Fir Wood in Hydrogen and Helium." Paper presented at the IGT's 8th Annual Meeting on Energy from Biomass and Wastes, BNL 34460, Lake Buena Vista, Florida, January 1984.

3. Steinberg, M., Fallon, P.T., and Sundaram, M.S. "Flash Pyrolysis of Biomass with Reactive and Non-Reactive Gases." Paper presented at the 188th ACS National Meeting, Symposium on Pyrolysis, Combustion/Gasification of Biomass, BNL 34510, Philadelphia, Pennsylvania, 26-31 August i984.

4. Steinberg, M., Fallon, P.T., and Sundaram, M.S. "Flash Pyrolysis of Biomass with Reactive and Non-Reactive Gases." Paper presented at the 16th Biomass Thermochemical Conversion Contractor's Meeting, BNL 34734 , Portland, Oregon, 8-9 May 1984.

\section{$\underline{\text { Patents }}$}

1. Steinberg, Meyer and Fallon, P.T. "Production of Chemical Feedstock by the Methanolysis of Wood", Patent Application BNL 82-52, S-59, 550 (1984). 
Table 1

Flash Methanolysis of Pine at 50 psi

\begin{tabular}{|c|c|c|c|c|c|c|c|c|c|c|c|}
\hline Run No. & 746 & 746 & 746 & 752 & 753 & 751 & 760 & 777 & 791 & 791 & 792 \\
\hline Reactor Temp. $\left({ }^{\circ} \mathrm{C}\right)$ & 900 & 950 & 1000 & 900 & 950 & 1000 & 1000 & 1000 & 1000 & 1000 & 1000 \\
\hline Wood Feed Rate $(\mathrm{lb} / \mathrm{hr})(1)$ & 0.55 & 0.55 & 0.55 & 0.51 & 0.52 & 0.44 & 0.62 & 1.47 & 2.56 & 2.56 & 2.56 \\
\hline Gas Feed Rate $(1 b / h r))$ & 3.84 & 3.84 & 3.84 & 4.21 & 4.14 & 4.12 & 3.75 & 5.83 & 3.37 & 6.59 & 9.97 \\
\hline Particle Res. Time (sec) & 1.1 & 1.2 & 1.3 & 1.2 & 1.2 & 1.2 & 1.3 & 0.9 & 1.4 & 0.8 & 0.6 \\
\hline Methane/Nood Ratio (1b/1b) & 6.98 & 6.98 & 6.98 & 8.25 & 7.96 & 9.36 & 6.05 & 3.97 & 1.32 & 2.57 & 3.89 \\
\hline \% Carbon Conv. to Prod. & & & & & & & & & - & & \\
\hline $\mathrm{C}_{2} \mathrm{H}_{4}$ & 15.7 & 20.6 & 27.4 & 16.1 & 22.4 & 29.6 & 18.5 & 22.5 & 7.5 & 14.7 & 15.6 \\
\hline $\mathrm{C}_{2} \mathrm{H}_{6}$ & 0 & 0 & 0 & 0 & 0 & 0 & & 1.4 & 0.4 & 1.5 & 2.1 \\
\hline Total Gas H.C. & $\overline{15.7}$ & $\overline{20.6}$ & $\overline{27.4}$ & $\overline{16.1}$ & $\overline{22.4}$ & $\overline{29.6}$ & $\overline{18.5}$ & $\overline{23.9}$ & $\overline{7.9}$ & $\overline{16.2}$ & $\overline{17.7}$ \\
\hline BTX & 11.9 & 13.4 & 24.6 & 8.0 & 19.7 & 23.7 & 19.7 & 20.8 & 13.8 & 17.0 & 14.6 \\
\hline Total H.C. & 27.6 & 34.0 & 52.0 & 24.1 & 42.1 & 53.3 & 38.2 & 44.7 & 21.7 & 33.2 & 32.3 \\
\hline CO & 35.6 & 36.1 & 38.7 & 38.5 & 39.0 & 45.2 & 40.2 & 37.7 & 26.6 & 35.8 & 33.8 \\
\hline $\mathrm{CO}_{2}$ & 2.4 & 2.4 & 2.7 & 3.1 & 2.9 & 3.0 & 3.0 & 2.3 & 2.4 & 3.0 & 2.9 \\
\hline Total $\mathrm{CO}_{\mathrm{x}}$ & $\overline{38.0}$ & $\overline{38.5}$ & $\overline{41.4}$ & $\overline{41.6}$ & $\overline{41.9}$ & $\overline{48.2}$ & $\overline{43.2}$ & $\overline{40.0}$ & $\overline{29.0}$ & $\overline{38.8}$ & $\overline{36.7}$ \\
\hline Total Con. & 65.6 & 72.5 & 93.4 & 67.5 & 84.0 & 101.5 & 81.4 & 84.7 & 50.7 & 72.0 & 69.0 \\
\hline Char & & & & 14.0 & 14.0 & & & & & & \\
\hline Total & & & & 79.7 & 98.0 & & & & & & \\
\hline $\mathrm{C}_{2} \mathrm{H}_{4}$ Conc. (Vol. $\left.\%\right)$ & 0.75 & 0.98 & 1.31 & 0.65 & 0.94 & 1.05 & 1.01 & 1.89 & 2.35 & 2.35 & 1.48 \\
\hline
\end{tabular}

1) Pine fed with $30 \%$ Cab-0-Sil 
Table 2

Degradation of Ethylene in Methane with Time and Temperature

Initial Concentration of Ethylene - $1.35 \%$ by volume

Methane Flow Rate - $4.31 \mathrm{lb} / \mathrm{hr}$

Reactor Pressure - 50 psig

\begin{tabular}{ccc}
\hline $\begin{array}{c}\text { Concentration } \\
(\text { volume \%) }\end{array}$ & $\begin{array}{c}\text { Gas Residence } \\
\text { Time }(\mathrm{sec})\end{array}$ & $\begin{array}{c}\text { Temperature } \\
\left({ }^{\circ} \mathrm{C}\right)\end{array}$ \\
\hline 1.25 & 0.5 & 900 \\
1.1 & 2.0 & 900 \\
1.15 & 0.5 & 1000 \\
0.92 & 2.0 & 1000 \\
0.9 & 0.5 & 1050 \\
\hline
\end{tabular}


Table 3

Flash Pyrolysis of Pine Wood with Helium at 50 psi

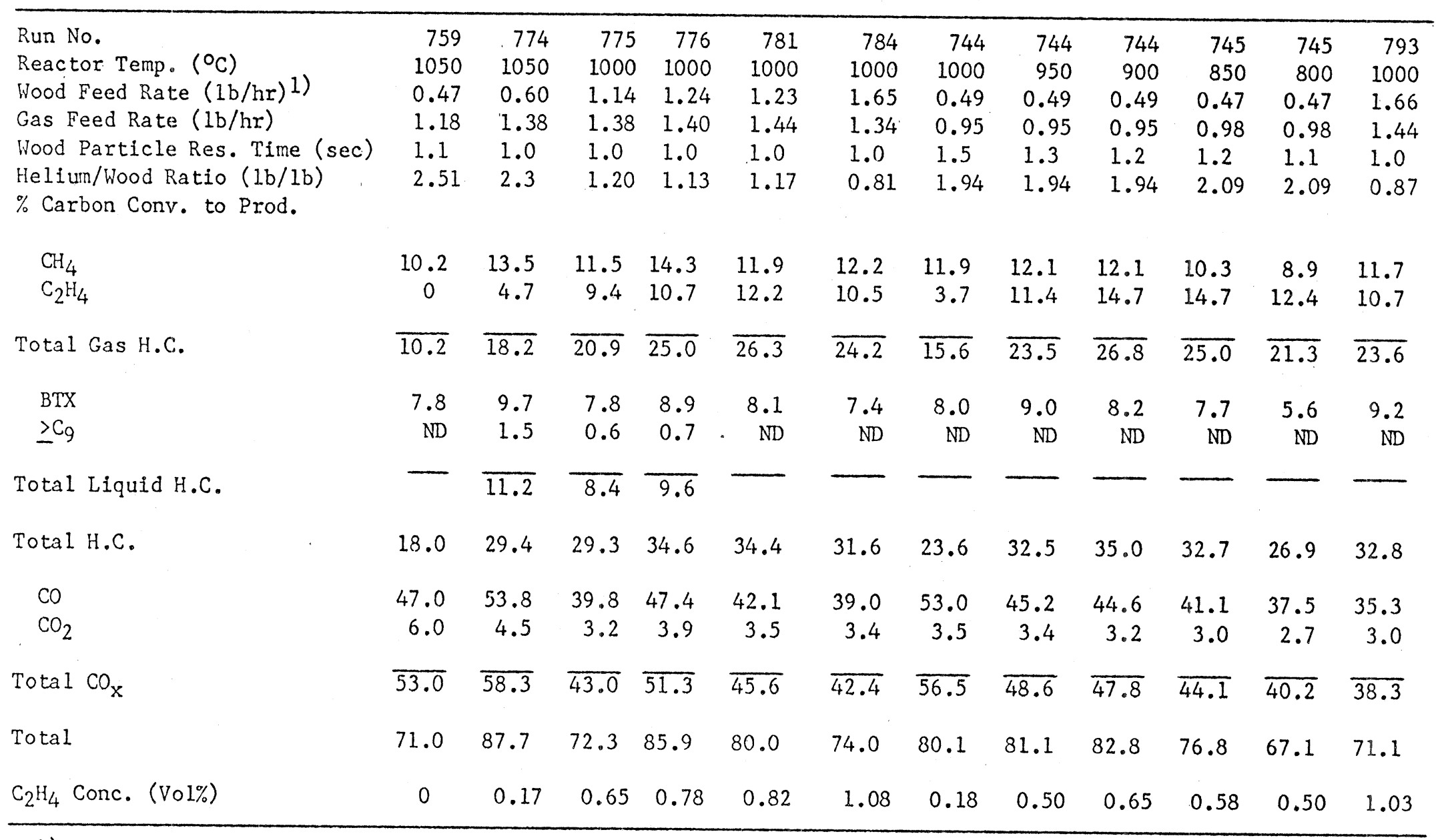

1) Fed with $30 \%$ Cab-0-Sil 
Table 4

Flash Methanolysis of Pine at 50 psi

\begin{tabular}{|c|c|c|c|c|}
\hline $\begin{array}{l}\text { Run No. } \\
\text { Additive } \\
\left.\text { Reactor Temp. ( }{ }^{\circ} \mathrm{C}\right) \\
\text { Wood Feed Rate (lb/hr) } \\
\text { Gas Feed Rate (lb/hr) } \\
\text { Wood Particle Res. Time (sec) }\end{array}$ & $\begin{array}{l}746 \\
\quad 30 \% \\
1000 \\
0.55 \\
3.84 \\
1.3\end{array}$ & $\begin{array}{c}751 \\
\mathrm{Cab}-0-\mathrm{Sil} \\
1000 \\
0.44 \\
4.12 \\
1.2\end{array}$ & $\begin{array}{l}768 \\
\frac{50 \% \text { Ash }}{1000} \\
1.04 \\
5.66 \\
0.9\end{array}$ & $\begin{array}{l}769 \\
\frac{60 \% \text { Ash }}{1000} \\
1.19 \\
5.02 \\
1.0\end{array}$ \\
\hline $\begin{array}{l}\text { \% Carbon Conv. to Prod. } \\
\mathrm{C}_{2} \mathrm{H}_{4} \\
\mathrm{C}_{2} \mathrm{H}_{6}\end{array}$ & $\begin{array}{c}27.4 \\
.0\end{array}$ & $\begin{array}{c}29.6 \\
0\end{array}$ & $\begin{array}{r}28.8 \\
2.7\end{array}$ & $\begin{array}{r}26.5 \\
2.0\end{array}$ \\
\hline Total Gas H.C. & & & & \\
\hline BTX & 24.6 & 23.7 & 17.8 & 17.0 \\
\hline Total H.C. & $\overline{52.0}$ & $\overline{53.3}$ & $\overline{49.3}$ & $\overline{45.5}$ \\
\hline $\begin{array}{l}\mathrm{CO} \\
\mathrm{CO}_{2}\end{array}$ & $\begin{array}{r}38.7 \\
2.7\end{array}$ & $\begin{array}{r}45.2 \\
3.0\end{array}$ & $\begin{array}{r}54.3 \\
9.0\end{array}$ & $\begin{array}{r}60.0 \\
3.8\end{array}$ \\
\hline Total $\mathrm{CO}_{\mathrm{x}}$ & $\overline{41.4}$ & $\overline{48.2}$ & $\overline{63.3}$ & $\overline{63.8}$ \\
\hline Total & 93.4 & 101.5 & 112.6 & 109.3 \\
\hline$\%$ Wt. Loss & 99.6 & $>100.0$ & 93.2 & 91.8 \\
\hline
\end{tabular}


Table 5

Flash Methanolysis

Run No.

Reactor Temp. $\left({ }^{\circ} \mathrm{C}\right)$

Reactor Pressure ( $p s i$ )

Wood Feed Rate ( $1 \mathrm{~b} / \mathrm{hr}$ )

Gas Feed Rate ( $1 \mathrm{~b} / \mathrm{hr}$ )

Wood Particle Res. Time (sec.)

\% Carbon Conv. To Prod.

$$
\mathrm{C}_{2} \mathrm{H}_{4}
$$$$
\mathrm{C}_{2} \mathrm{H}_{6}
$$

Total Gas H.C.

BTX

$\geq \mathrm{Cg}$

Total Liquid H.C.

CO

$\mathrm{CO}_{2}$

Total $\mathrm{Co}_{\mathrm{x}}$

Tota 1 Conv.

\begin{tabular}{cc} 
Douglas Fir Wood & Kraft Pine Lignin \\
\hline 590 & 737 \\
900 & 900 \\
50 & 50 \\
0.89 & 0.55 \\
4.21 & 3.99 \\
0.9 & $\sim 1.0$ \\
& \\
13.0 & 5.1 \\
2.2 & 0 \\
15.2 & $\overline{5.1}$ \\
5.8 & 7.3 \\
1.4 & $\mathrm{ND}$ \\
7.2 & -
\end{tabular}

47.7

2.5

10.2

1.9

$\overline{50.2}$

$\overline{12.1}$

72.6

24.5

(1) With Addition of $15 \%$ Cab-0-Sil

(2) With Addition of $20 \%$ Cab-O-Sil 
Flash Methanolysis of Pine at 50psi

Reactor Temp. vs Hydrocarbon Product Yield

Wood Particle Residence Time -1.1 to $1.3 \mathrm{sec}$.

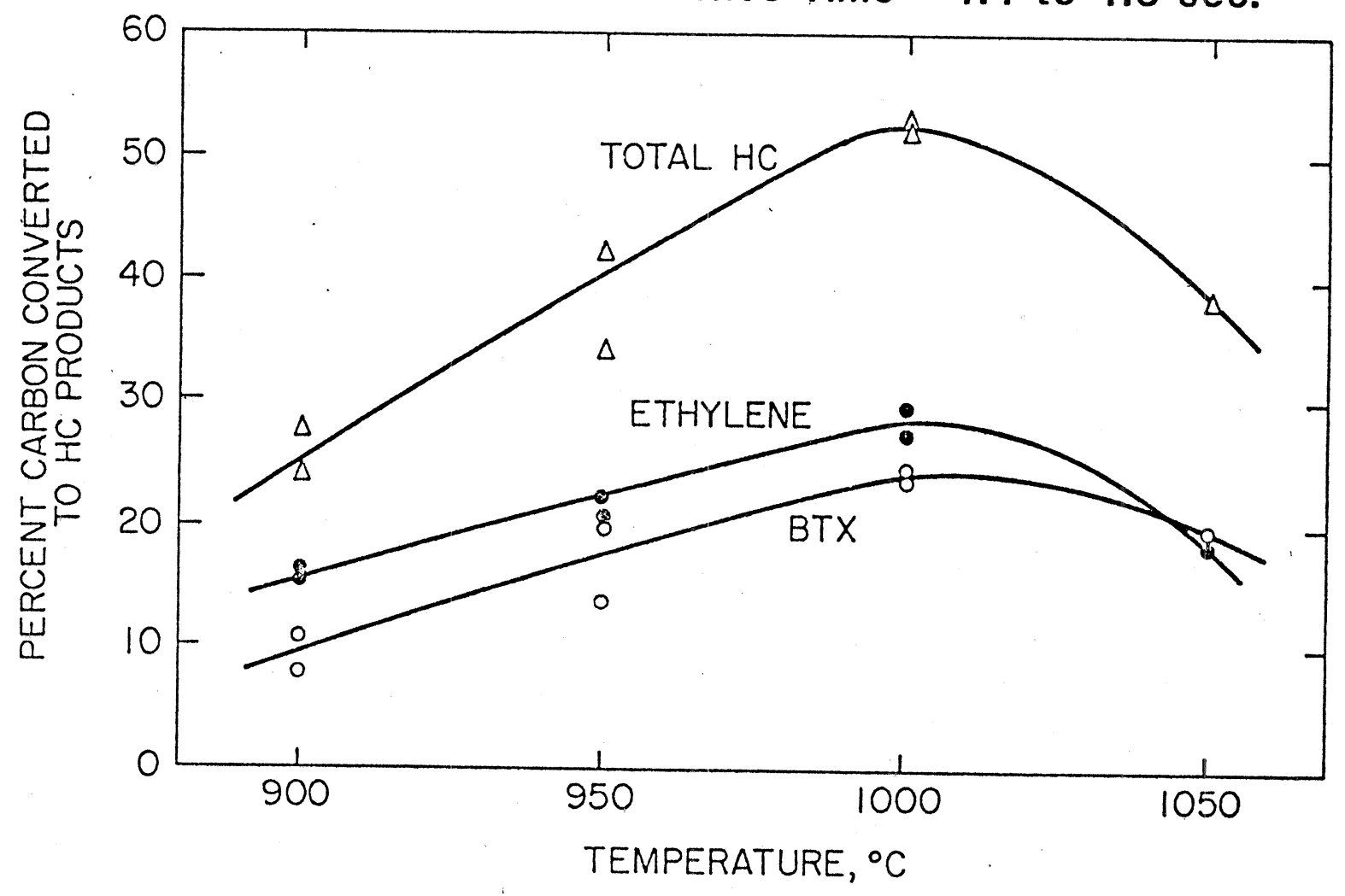


FLASH PYROLYSIS OF PINE WOOD IN HELIUM HYDROCARBON YIELD VS. HELIUM / WOOD RATIO

REACTOR TEMP $-1000^{\circ} \mathrm{C}$

REACTOR PRESSURE - $50 \mathrm{psi}$

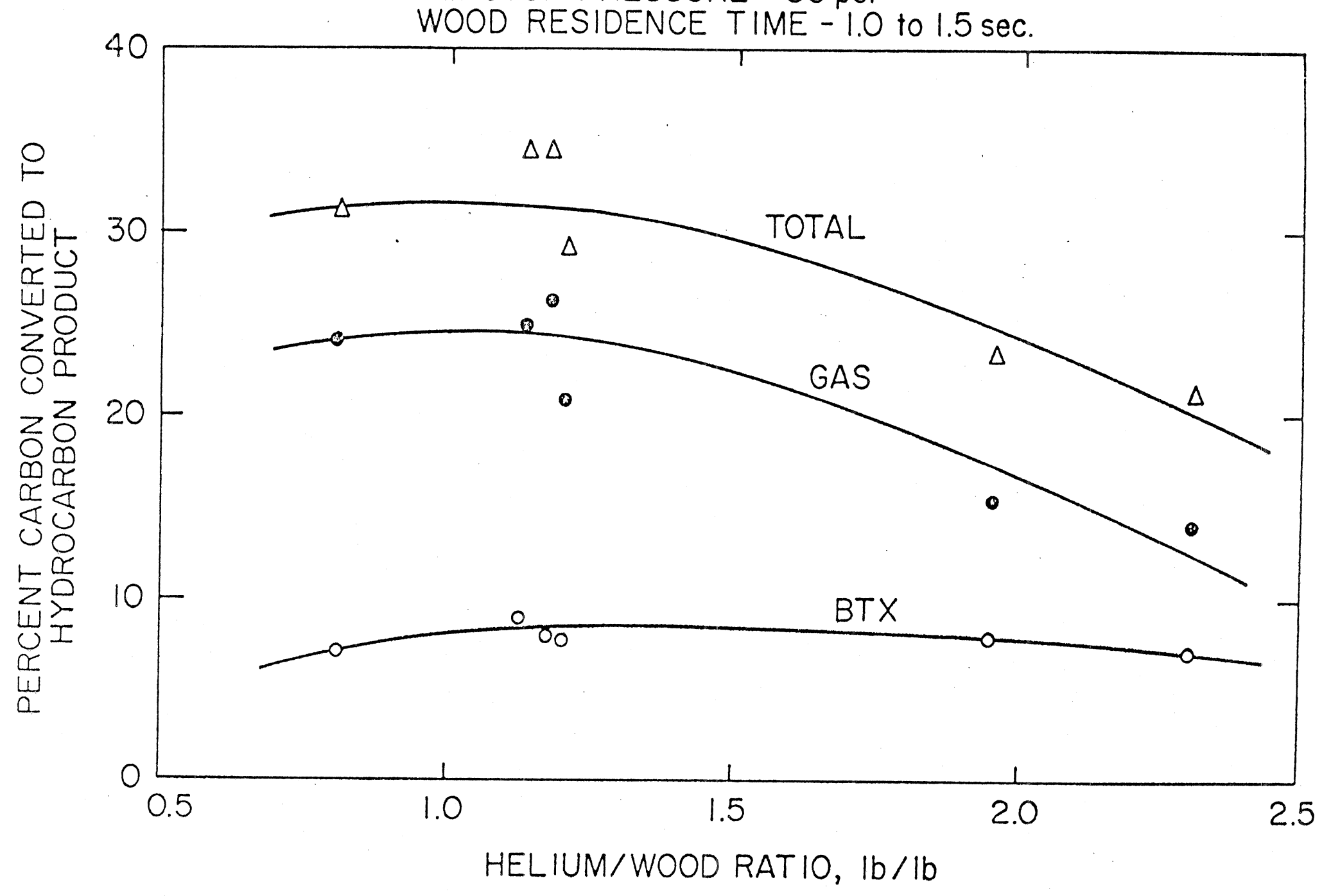

FIGURE 5 
FLASH PYROLYSIS OF PINE WOOD IN HELIUM

ETHYLENE YIELD \& PRODUCT CONCENTRATION VS. HELIUM/WOOD RATIO

REACTOR TEMP. $-1000^{\circ} \mathrm{C}$

REACTOR PRESSURE - 50 psi

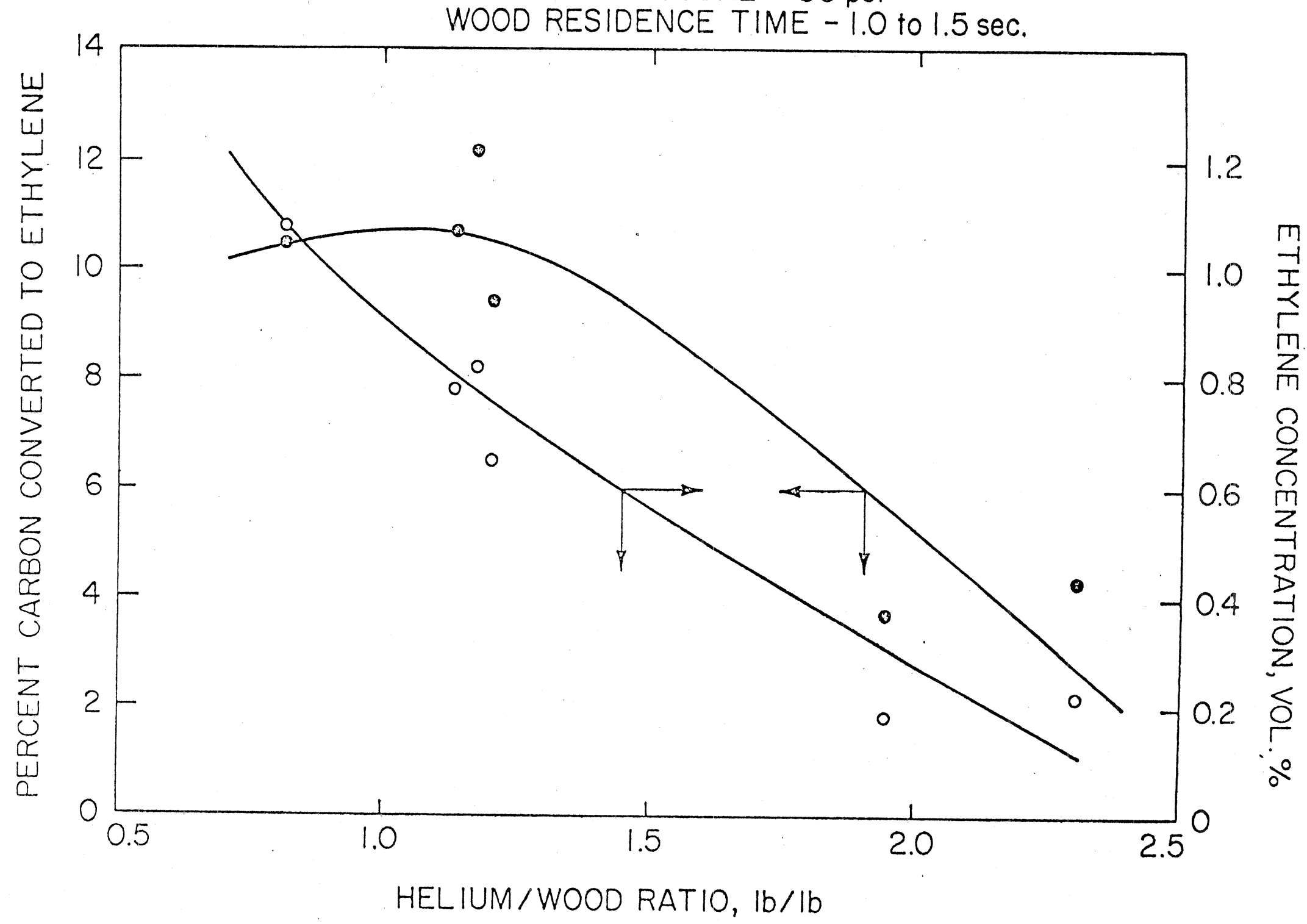

FIGURE 6 
